\title{
Innovative Structural Concept \& Solution for Mega Tall Buildings Applied to One Kilometer Skyscraper
}

\author{
Feroz Alam \\ Civil Engineering, The Institute of Engineers, Dhaka, Bangladesh \\ Email: ferozalamabc@yahoo.com
}

How to cite this paper: Alam, F. (2017) Innovative Structural Concept \& Solution for Mega Tall Buildings Applied to One Kilometer Skyscraper. Open Access Library Journal, 4: e3459.

https://doi.org/10.4236/oalib.1103459

Received: February 16, 2017

Accepted: April 14, 2017

Published: April 17, 2017

Copyright (c) 2017 by author and Open Access Library Inc.

This work is licensed under the Creative Commons Attribution International License (CC BY 4.0).

http://creativecommons.org/licenses/by/4.0/ (c) (i) Open Access

\begin{abstract}
Structural systems for tall buildings have undergone dramatic changes since the demise of the conventional rigid frames in the 1960s as the predominant type of structural system for steel or concrete tall buildings. Generally, the structural systems of tall buildings are considered to be two types. One is interior and the other one is exterior type. The frame tube buildings have been the most efficient structural system used for building which is in the range of 40 100 stories. In the early 1970s, Fintel (1974) indicated that properly designed structural walls could be used effectively as the primary lateral-load resisting system for both wind and earthquake loading in multistory buildings. This study is intended to model an advanced structural system for tall buildings. In this innovative concept, several parallel shear walls have been arranged in both directions and connected with beams and R.C. floor slabs. The shear walls are continuous down to the base to which they are rigidly attached to form vertical cantilevers. Their high in plane stiffness and strength make them well suited for bracing buildings up to about 278 stories. Also it is found by research that, when this structural arrangement is applied to around 830 meter tall structure with aspect ratio 8.14:1, no additional structural supporting system is required. This shear walls arrangement is applicable for the tall buildings of any height to avoid additional supports to resist the lateral forces while taking advantage of the creative approach of this unique concept.
\end{abstract}

\section{Subject Areas \\ Civil Engineering}

\section{Keywords}

Innovative, Drift, Outriggers, Skyscraper, Tall Buildings 


\section{Introduction}

After the Great Chicago Fire in 1871 that left a big part of downtown Chicago empty, higher buildings started to emerge. A tall building is not defined by its height or number of stories. The important criterion is whether or not the design is influenced by some aspect "tallness". It is a building in which tallness strongly influences planning, design, construction and use. It is a building whose height creates conditions different from those that exist in common buildings of a certain region and period [1]. There are physical, code prescribed and practical reasons why tall buildings tend to be safer than low-rise buildings [2]. Undoubtedly, the factor that governs the design of a tall and slender structure most of the times is not the fully stressed state, but the drift/acceleration of the building for wind loading. It is easy to understand that the higher the building is, the more important its lateral behavior becomes. Thus, to understand the performance of high-rise buildings, the lateral resisting system of tall buildings becomes a key factor that needs to be investigated and understood.

In 1969, Fazlur Rahman Khan classified structural systems for tall buildings relating to their height with considerations for efficiency in the form of "Height for Structural Systems" diagram for both steel and concrete in Figure 1 (Ali, 2001, Ali \& Armstrong, 1995; Schueller). This marked the beginning of a new era of skyscraper revolution in terms of multiple structural systems. Feasible structural systems, according to him, are rigid frames, frame shear trusses, belt trusses, framed tubes, truss-tube with interior columns, bundle tubes and truss-tube without interior columns [3]. These structural systems can reach up to about 140 stories.

The objective of this paper is to apply a new "Parallel Shear Walls Concept" to 1000.8 meter tall structural model that consists of five vertical portions (Figure 2 \& Figure 3), which cover 278 stories taller than the existing tallest building in the world. Building details are shown in Table 1 . To gain an adequate footprint for stability, this tower extends to nearly $102 \mathrm{~m} \times 102 \mathrm{~m}$ at base, resulting in the 9.8:1 aspect ratio (The ratio of the height of the building to its smaller width at the base), exceeds the one held by existing tallest building in the world, Burl Khalifa which is close to 9:1 [4].

In this "Parallel Shear Walls Concept", as grids contain a number of shear walls, these shear walls near the perimeter undergo maximum stresses due to wind force and the stresses linearly decrease towards the core and it is minimum at the center of the building, i.e. all the shear walls in a grid taking part to resist the wind force. All the grids in each side of the building are resisting the wind forces. So the axial deformation of all the walls in a raw is nearly same. Therefore no "shear lag effect" will occur. On the other hand, the walls are connected by rigid beams to form vertical cantilever, when the walls deflect under the action of the lateral forces, the connecting beam's ends are forced to rotate and displace vertically, so those beams bend in double curvature and thus resist the free bending of the walls [[5], p. 214]. But for the exterior or interior tube systems (tubular frames), the wind loads are resisted and concentrated on peripheral columns or to the inner core respectively. When the corner columns of the 

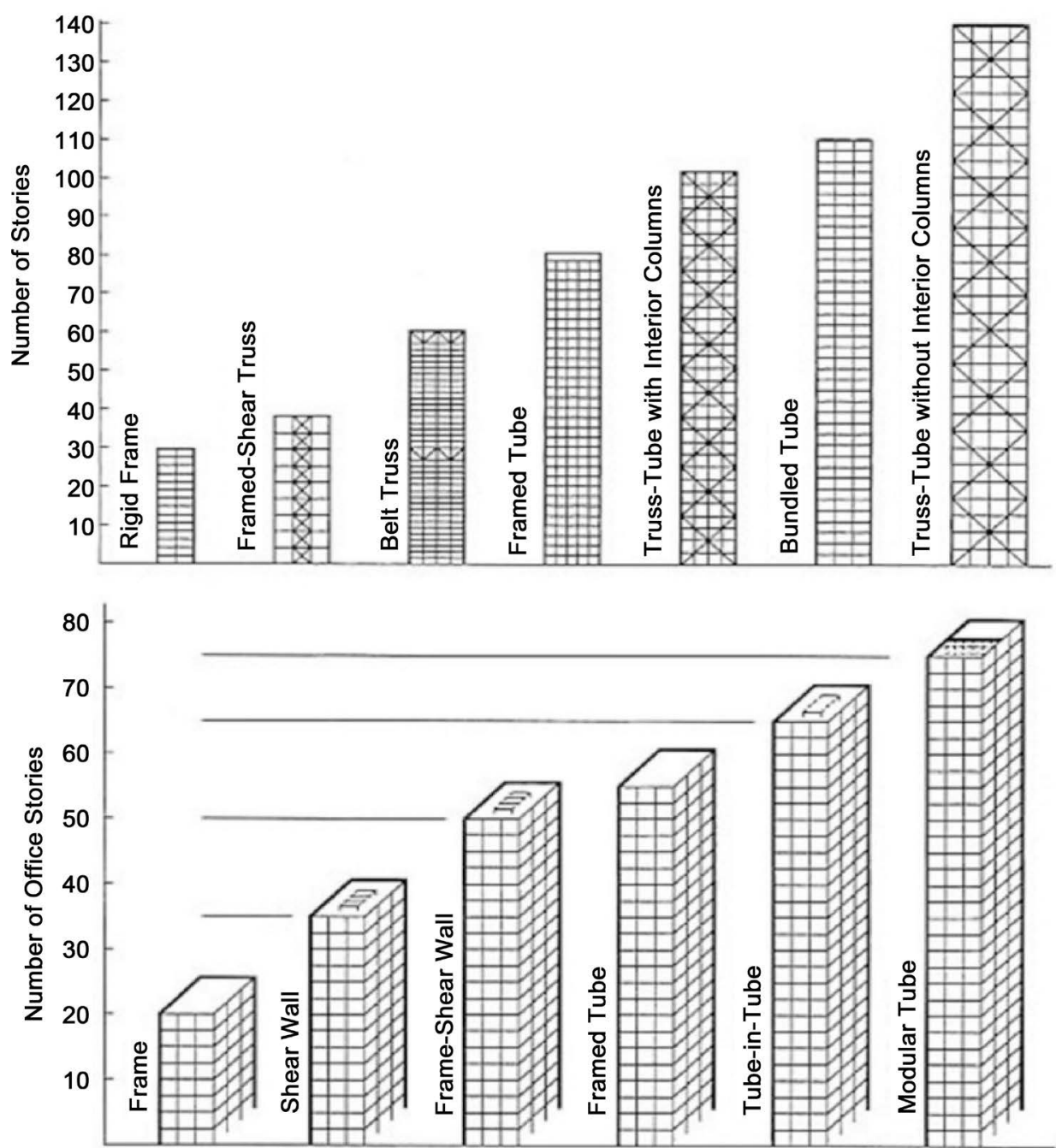

Figure 1. Classification of tall building structural systems by Fazlur Khan (above: steel; below: concrete) [3].

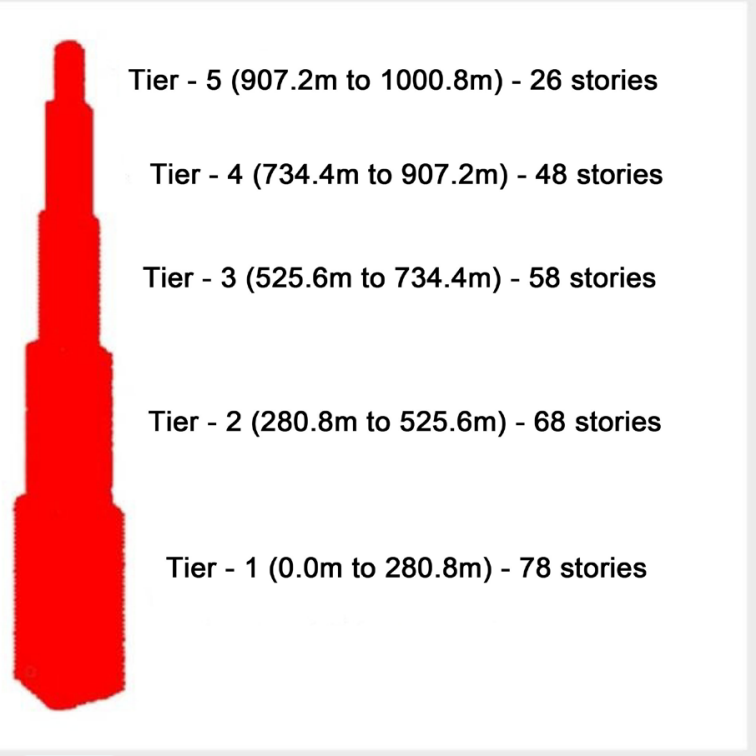

Figure 2. Levels and number of stories. 


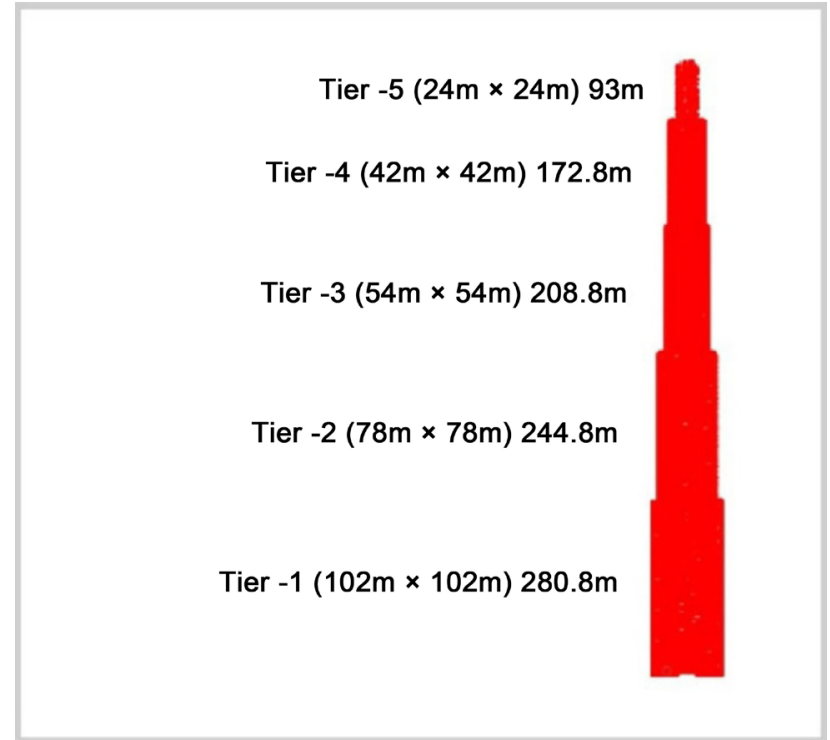

Figure 3. Floor dimensions and Tier heights.

Table 1. Building's Data.

\begin{tabular}{|c|c|}
\hline Height-ground floor to roof & 3282 feet $(1000.8 \mathrm{~m})$ \\
\hline Number of stories & 278 \\
\hline Building uses (assumed) & Hotel, office and residential \\
\hline Frame materials & Concrete structure \\
\hline Typical floor live load & $3 \mathrm{kn} / \mathrm{m}^{2}(60 \mathrm{psf})$ \\
\hline $\begin{array}{l}\text { Basic wind velocity ( } 100 \text { years returned period for Qatar, wind } \\
\text { load considered for Qatar) }\end{array}$ & $41.67 \mathrm{~m} / \mathrm{sec}(150 \mathrm{~km} / \mathrm{hour})$ \\
\hline $\begin{array}{l}\text { Allowable Sway (Drift) [6]-(commentary appendix C-Sec: } \\
\text { CC.1.2 ASCE 7-10) }\end{array}$ & $\mathrm{H} / 500(\mathrm{H}=$ height of the structure $)$ \\
\hline Allowable sway at top of author's tower & $1000.8 \mathrm{~m} / 500=2001.6 \mathrm{~mm}\left(6^{\prime}-6^{\prime \prime}\right)$ \\
\hline Sway of the tower at top for dynamic analysis & $1930 \mathrm{~mm}\left(6^{\prime}-4^{\prime \prime}\right)$ \\
\hline Type of structure & $\begin{array}{l}\text { Arrangements of concrete shear walls and beams for Tier-1, Tier-2, Tier-3 } \\
\text { and Tier- } 4 \text {. Tier- } 5 \text { is the frame structure }\end{array}$ \\
\hline Foundation type & Future assignment \\
\hline Typical floor height & $3.6 \mathrm{~m}$ \\
\hline Floor type & R.C.C. Slab \\
\hline Shear wall spacing & $12 \mathrm{~m}, 9 \mathrm{~m} \& 6 \mathrm{~m} \mathrm{c} / \mathrm{c}$ \\
\hline Core area & Column-beam framing \\
\hline Shear wall thicknesses at ground floor & $1.6 \mathrm{~m}, 1.5 \mathrm{~m}, 1.4 \mathrm{~m} \& 1.3 \mathrm{~m}$, gradually decreasing the thicknesses toward top \\
\hline Typical beam sizes & Depth $0.8 \mathrm{~m}$, width $1.1 \mathrm{~m} \& 1.2 \mathrm{~m}$ \\
\hline Column spacing & $6 \mathrm{~m}$ (20 feet) $\mathrm{c} / \mathrm{c}$ \\
\hline Column sizes at base & $1.5 \mathrm{~m} \times 1.5 \mathrm{~m}$ \\
\hline Covered area at base by shear walls \& columns & $14.53 \%$ \\
\hline Concrete strength & Shear walls \& columns $80 \mathrm{MPa}$, beams \& slab $40 \mathrm{MPa}$ \\
\hline Aspect ratio (building height/least length at base) & $9.8: 1$ \\
\hline
\end{tabular}




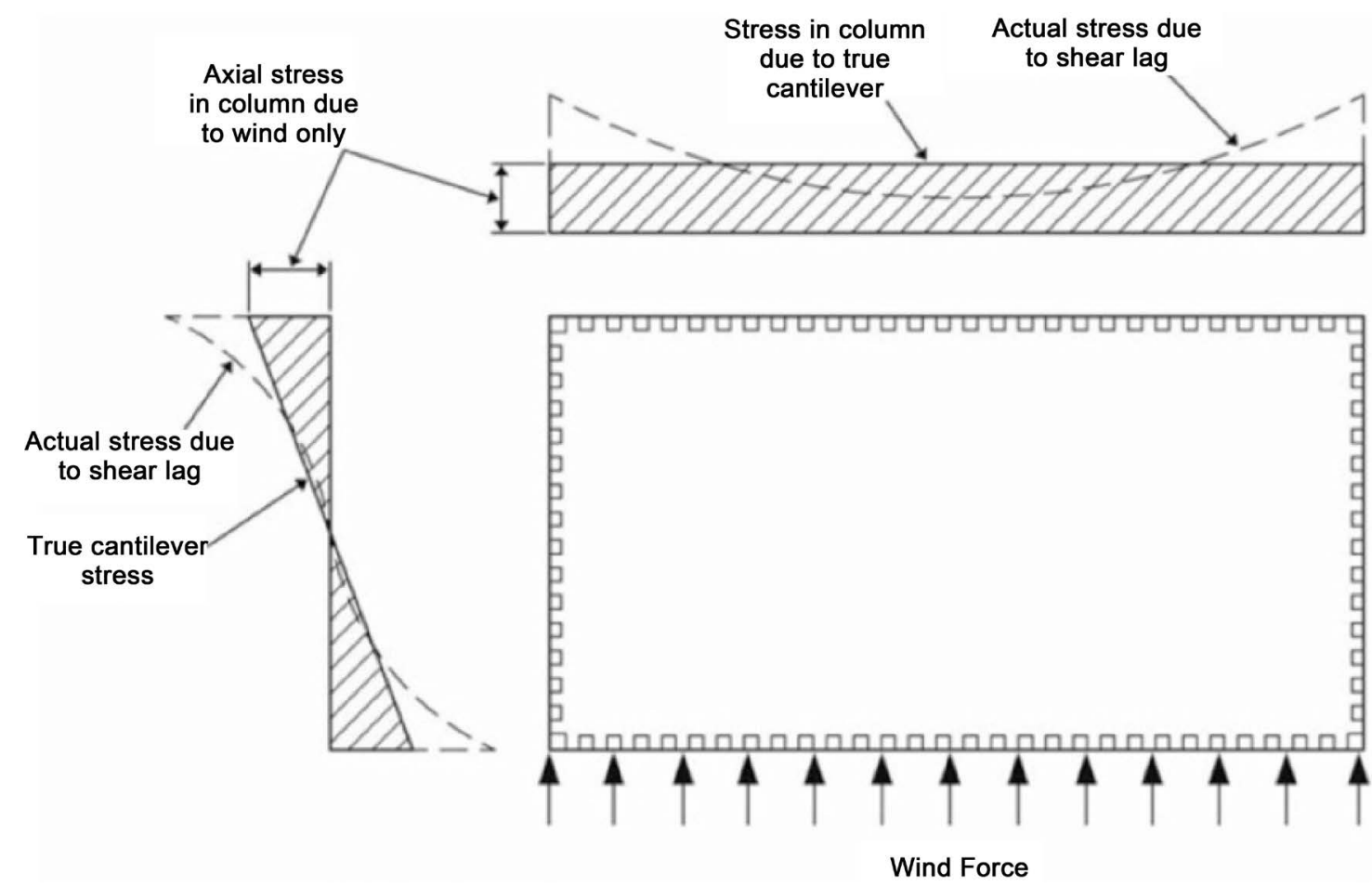

Figure 4. Axial stress distribution in columns of laterally loaded framed tube [3].

periphery suffer a compressive deformation, it will tend to compress the adjacent column, since the two are connected by the spandrel beams. The compressive deformations will not be identical (Figure 4) since the flexible connecting spandrel beam will bend, and the axial deformation of the adjacent column will be less, by an amount depending on the stiffness of the connecting beam. Each successive interior column will suffer a smaller deformation and hence a lower stress than the outer one [5]. This phenomenon is called the shear lag effect. Shear lag may lead to wrapping of floor slabs, local bulking on compression side \& cracking on tension side.

This is a theoretical study so the author's intension is to use the top of the structure as a habitable floor maximizing the total floor area to increase high value lease spaces. Usually the gross floor area can be reduced by making three voids from top to bottom on each side of the building perimeter. These voids will reduce up to $30 \%$ from Tier-1, 28\% from Tier-2 \& 8\% from Tier-3. Besides, the central core area is so far from any natural light at the perimeter, can be a central void further to reduce the floor area. Because making voids will give negligible effect on the structural behavior. But the beams and columns will remain in the same position to transfer wind forces through the grids.

\section{Primary Structural Arrangement}

The tower is characterized by its symmetry. There are no transfers of vertical elements through the main body of the tower. It allows a uniform distribution of gravity forces through the structure. These characteristics allow for a more efficient structure. 


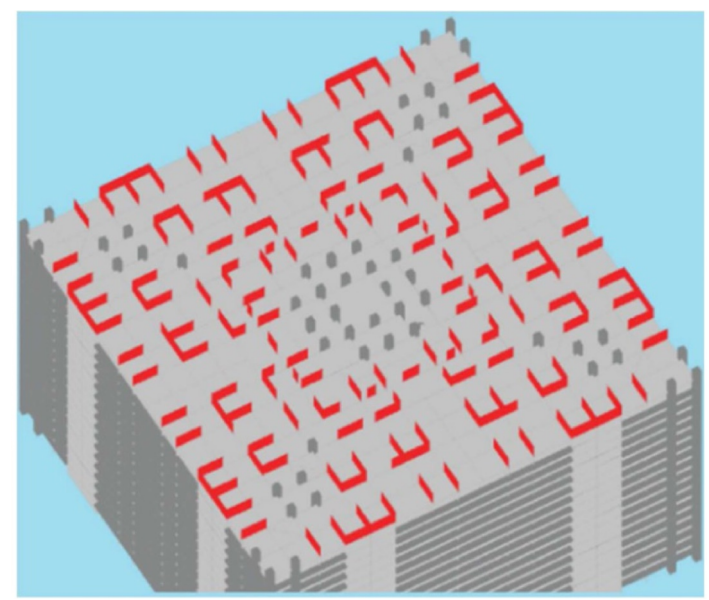

Figure 5. Floor layout in relation to structure (Shear walls marked red color \& columns marked ash color are shown on the typical floor of Tier-1).

There is no separation between the gravity system and the lateral system. The vertical structure is organized in such a way that the elements are all sized on sufficient lateral stiffness while at the same time providing strength consideration. This creates an extremely efficient structure where the materials perform double-duty (gravity and lateral support). This structure creates a uniform distribution of load reducing the differential shortening.

The building has 5 Tiers of different heights (Figure 2 \& Figure 3).

The structural system consists of several parallel shear walls in each direction of the faces of building (Figures 5-10) which are essentially analogous with the buildings' central core columns, coupling beams and conventionally reinforced concrete floor framing. This produces a completely interconnected structural system (Figure 5). The shear wall arrangements of this tower are in such a way that they provide large amount of inertia forces and stiffness to the structure. So the amount of moments carried by the beams due to wind is less. Therefore the author has selected the depth of $0.8 \mathrm{~m}$ and width $1.1 \mathrm{~m}$ of all the beams for theoretical purposes. However, maximum sizes of few beams will be $1.3 \mathrm{~m}$ $($ depth $) \times 1.4 \mathrm{~m}$ (width) near the Tier-1 during practical application as the author checked the maximum moments.

Each side of the building will resist the wind force by several parallel shear walls. The wind forces will be distributed to the structure almost uniformly to all grids due to the shear wall placements (Figure 6). Each Tier has its own core which starts from base. Several experiments show that Tiers with different heights (height of Tier-1 will be longest and gradually decrease the Tier heights towards top) give better results than the Tiers of uniform height.

In this structural system the corner portions of the Tier-1, Tier-2 \& Tier-3 are kept free from shear walls for views \& lightings which makes the highest value lease spaces (Figures 7-9). Figures 7-12 (Typical Floors of different Tiers) show the structural arrangement of typical floors of five different Tiers of the building $\&$ the members marked maroon are the shear walls lay-out and members marked sky blue are the columns lay-out and beams. Beams are not shown in Figures 
7-10. Figure 12 is the typical floor of Tier-1. Connections of shear walls, columns and beams of a typical floor are shown in Figure 12. Same structural connections will be followed for Tier-2, Tier-3, Tier-4 \& Tier-5 as shown in Figure 12.

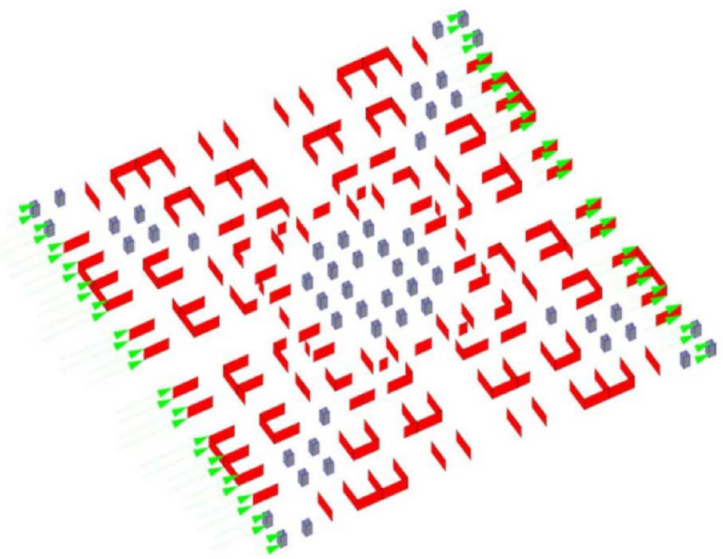

Figure 6. Wind forces are distributed in all grids (Members marked red \& ash in Figure 5 \& Figure 6 are shear walls and columns lay-out respectively).

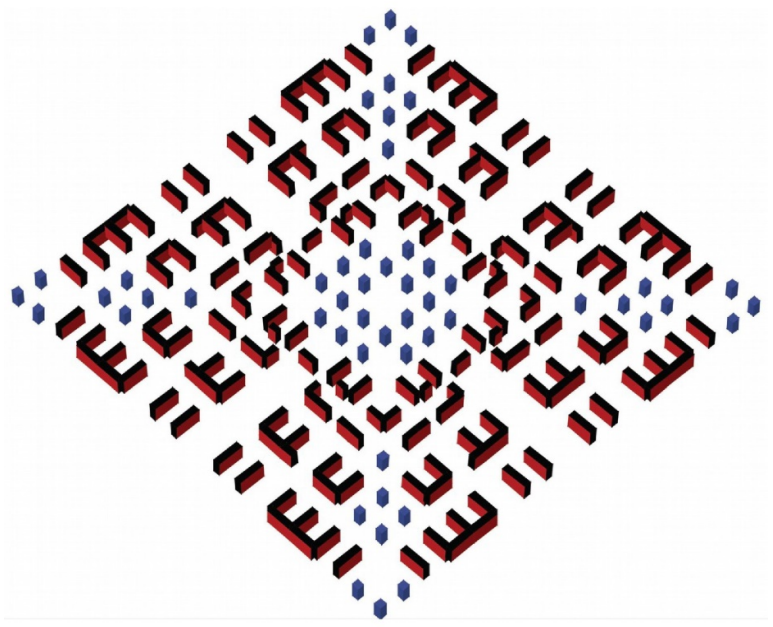

Figure 7. Typical shear walls \& columns arrangement of Tier-1.

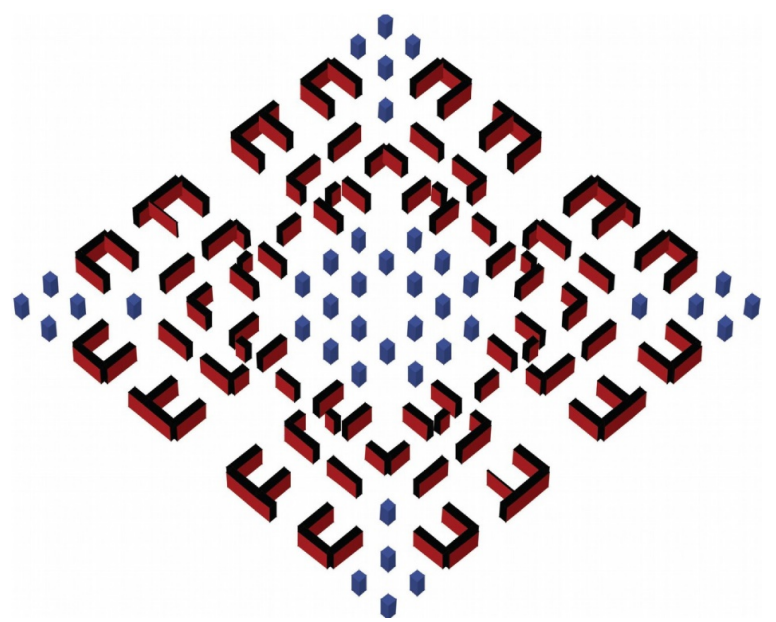

Figure 8. Typical shear walls \& columns arrangement of Tier-2. 


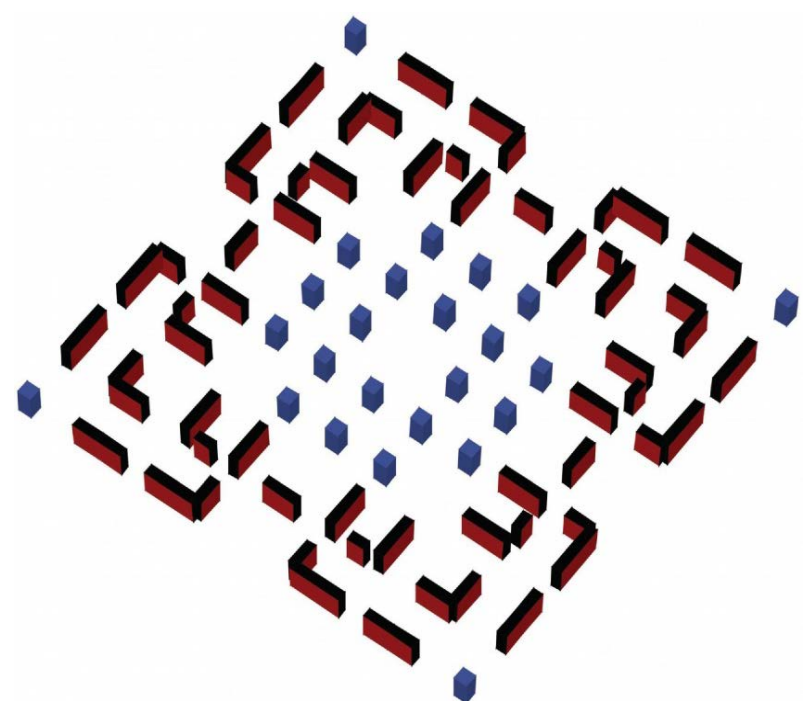

Figure 9. Typical shear walls \& columns arrangement of Tier-3.

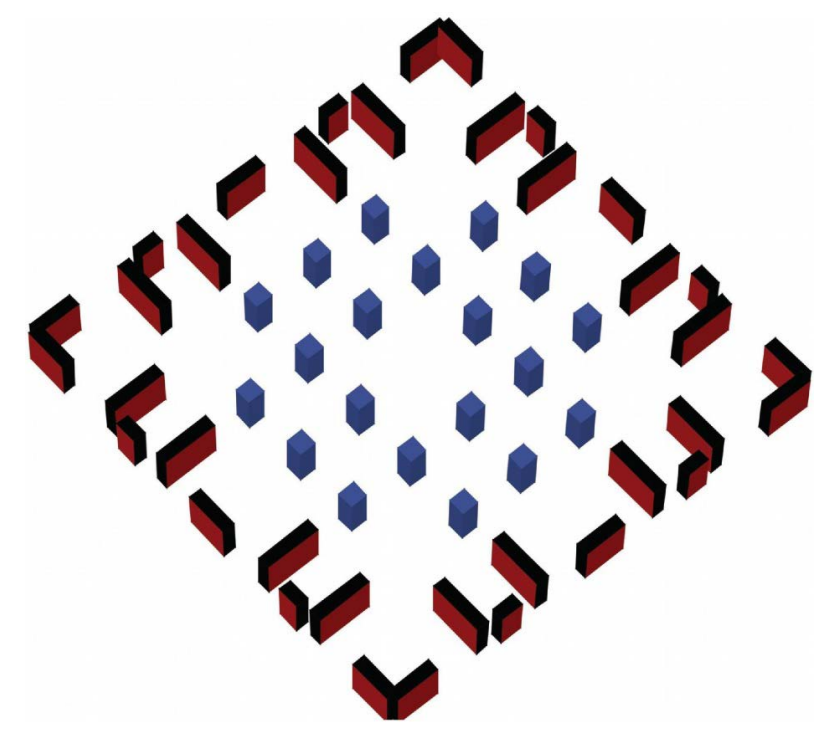

Figure 10. Typical shear walls \& columns arrangement of Tier-4.

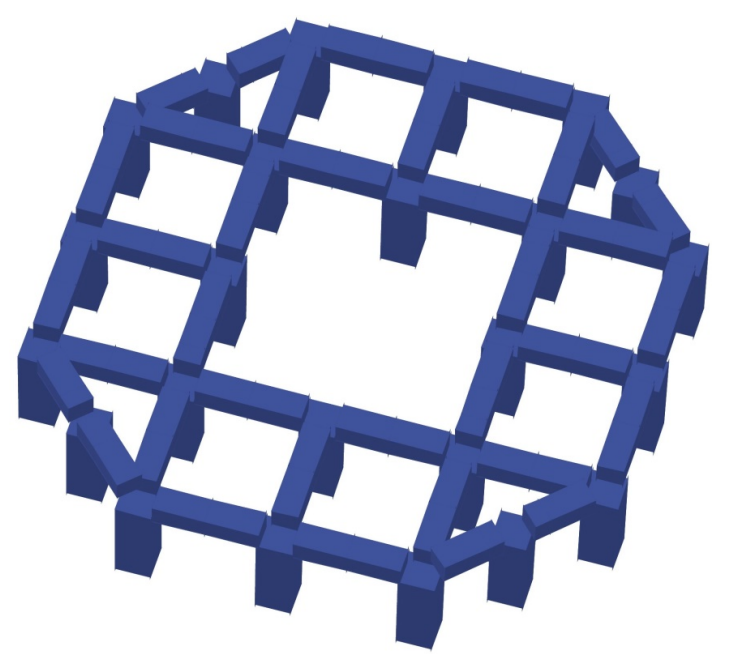

Figure 11. Frame structure of Tier-5 (Typical Floor). 


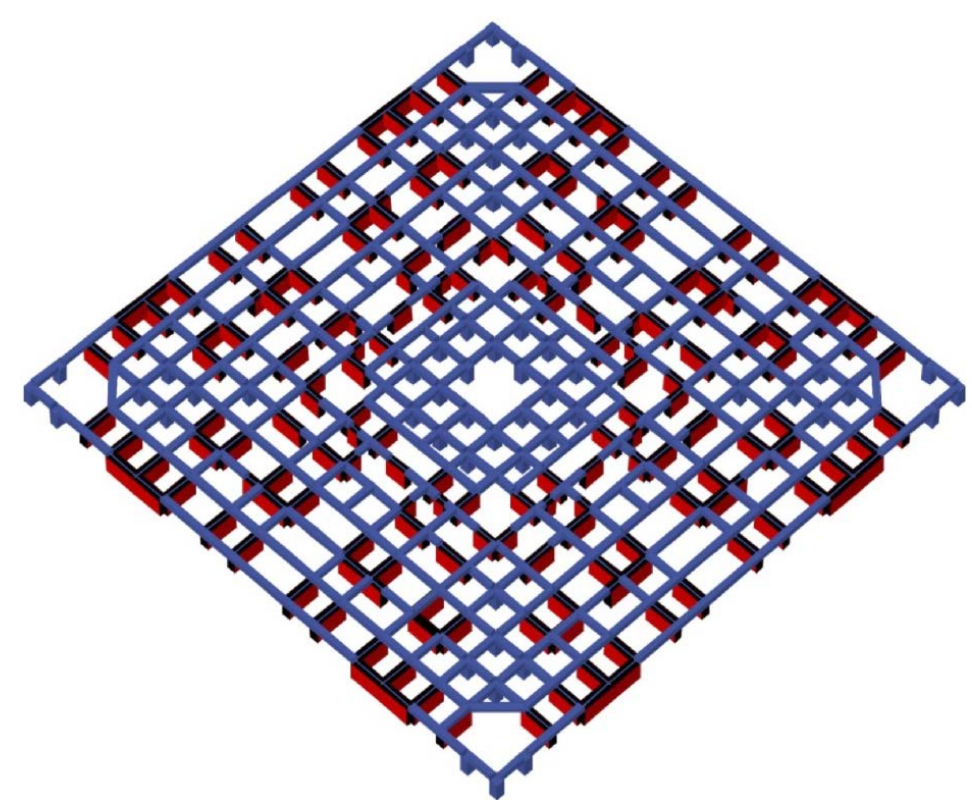

Figure 12. Interaction between shear walls, columns \& beams.

The Tier-5 is a frame structure started from base and is composed of reinforced concrete beams, columns and slabs (Figure 11).

Various options have been studied through this parametric modeling method. The main goals were to maximize the lever arm of the shear walls, maintain the shear wall line in one single vertical plan, so as to minimize secondary forces. This shear wall arrangement can be said as an optimal balance and the most effective lateral load-resisting structure to stabilize this mega tall structure.

Cracked sections have been considered in the analysis and therefore moment of inertia has been taken half of the amount of no crack section.

Base area of Tier-1 is maximum while base areas of other Tiers gradually decreasing towards the top. The author has chosen and tuned the height increments towards bottom and gradually decreasing towards top because the moments and the shears are high at the bottom. Tower design of any height with this "Parallel Shear Wall Concept", the structural engineers will have to tune and choose the different heights of the Tiers accordingly.

\section{Results Analysis}

Drift Limits in common usage for building design are in the order of 1/600 to $1 / 400$ of the building height (ASCE). Generally, for tall buildings allowable drift is considered as H/500, which becomes $2001.6 \mathrm{~mm}$ for this "One Kilometer Structure".

The dynamic analysis (Time History Analysis) for wind has been carried out by STAAD/PRO. Table 2 shows the results for dynamic \& static analysis at the top.

SRSS value for six Modes (Square Root of the Sum of Squares) of dynamic wind analysis is $1995 \mathrm{~mm}$.

Dynamic analysis of this $1 \mathrm{Km}$ tower shows that the habitable/usable floor is at height $723 \mathrm{~m}$ (Record breaking habitable height at 201 story) where accelera- 
Table 2. Drift at the top of the Structure.

\begin{tabular}{cc}
\hline Building's height & 1000.8 meters \\
Drift for static analysis & $1884 \mathrm{~mm}$ \\
Drift for dynamic analysis & $1930 \mathrm{~mm}$ \\
\hline
\end{tabular}

Table 3. Configurations of some TDMs currently in use.

\begin{tabular}{|c|c|c|}
\hline Host Structures & Descriptions & Results \\
\hline $\begin{array}{c}\text { Hancock Tower }(244 \mathrm{~m}) \text { in } \\
\text { Boston, USA }\end{array}$ & $\begin{array}{l}\text { Two TMDs were installed at } \\
\text { opposite ends of } 58 \text { th floor, each } \\
\text { weighing } 300 \text { tons }\end{array}$ & $\begin{array}{l}\text { Can reduce building's } \\
\text { response } 50 \%[7]\end{array}$ \\
\hline $\begin{array}{l}\text { Citicorp Building }(278 \mathrm{~m}) \\
\text { in New York, USA }\end{array}$ & $\begin{array}{l}\text { A } 40 \text { ton concrete block with two } \\
\text { spring damping mechanisms } \\
\text { installed in } 63 \text { rd floor }\end{array}$ & $\begin{array}{l}\text { Reduces wind induced } \\
\text { response } 40 \% \text { [7] }\end{array}$ \\
\hline $\begin{array}{c}\text { Sydney Tower }(305 \mathrm{~m}) \text {, } \\
\text { Australia }\end{array}$ & $\begin{array}{l}\text { Doughnut-shaped water tanks \& } \\
\text { energy dissipating shock absorbers }\end{array}$ & $\begin{array}{l}\text { Response reduced } 40 \% \text { - } \\
50 \%[7]\end{array}$ \\
\hline $\begin{array}{c}\text { Sendai AERU (145.5 m) } \\
\text { IN Sendai }\end{array}$ & $\begin{array}{l}\text { TMD w/laminated rubber bearing } \\
+ \text { coil spring }\end{array}$ & Response reduced 1/2 [7] \\
\hline $\begin{array}{l}\text { Petronas Twin Tower ( } 452 \\
\text { m) in Kuala Lumpur }\end{array}$ & 12 Fluid Dampers & $\begin{array}{l}\text { Prevent vortex shedding \& } \\
\text { reduce wind-induced } \\
\text { excitation [7] }\end{array}$ \\
\hline $\begin{array}{l}\text { Taipei } 101 \text { Skyscraper } \\
(509.2 \mathrm{~m}) \text { in Taiwan }\end{array}$ & $\begin{array}{l}\text { Installed world's largest \& heaviest } \\
\text { TDMs weighing } 728 \text { short-ton }\end{array}$ & $\begin{array}{l}\text { To offset movements in the } \\
\text { building caused by strong } \\
\text { gusts [8] }\end{array}$ \\
\hline $\begin{array}{l}\text { Burj Al Arab }(321 \mathrm{~m}) \text { in } \\
\text { Dubai }\end{array}$ & Installed 11 TMDs & $\begin{array}{l}\text { Reduced wind induced } \\
\text { response [9] }\end{array}$ \\
\hline
\end{tabular}

tion is 30 milli-g which is acceptable according to NBCC 1990 [10].

Whereas the habitable floor level for the existing tallest building of the world at the height of $584.5 \mathrm{~m}$ (154th Story).

Damping is an important issue as the human comfort due to excessive acceleration beyond 25 milli-g, in the range of 35 to 50 milli-g, may have to be designed for. Tuned mass dampers and viscoelastic dampers are often used [11].

Acceleration due to dynamic analysis at top is 47.7 milli-g. It is seen that Tuned Mass Dampers (TMDs) transmit inertial force to the building's frame to reduce its motion around up to $50 \%$. Therefore 47.7 milli-g acceleration of this 1 $\mathrm{Km}$ tower can be reduced by introducing Tuned Mass Damper accordingly to make this height habitable floor level.

In Table 3, there are some examples of tall buildings which reduced their accelerations by introducing TDMs.

Vanity/Spire height: In theory, we're in the midst of a "golden age" of skyscraper construction. But why, of the ten tallest building on Earth, nearly 30 percent of each structure totally unusable spire? In truth, this information is readily available to anyone with eyeballs. All supertalls (e.g., any building over 1000 feet tall) have substantial spires and unoccupied upper floors, which serve to house hardware, observation decks, and often, mass damper that counter the sway 
Table 4. Vanity Height of the Towers [12].

\begin{tabular}{cccc}
\hline Towers & $\begin{array}{c}\text { Total Height } \\
\text { (Meters) }\end{array}$ & $\begin{array}{c}\text { Vanity Height } \\
\text { (Meters) }\end{array}$ & $\begin{array}{c}\text { Percentage of } \\
\text { Vanity heights }\end{array}$ \\
\hline Zifeng Tower-China & 450 & 133 & 30 \\
Bank of America Tower-New York & 366 & 131 & 36 \\
Burj Al-Arab-Dubai & 321 & 124 & 39 \\
Emirates Tower One-Dubai & 355 & 133 & 32 \\
New York Times-New York & 319 & 99 & 31 \\
Nakheel Tower-Dubai & 1000 & N/A & 10 \\
\hline
\end{tabular}

of the building in the wind. But even taking into account the necessary infrastructure, the majority of spires are totally unnecessary.

In fact, without the vanity height, 60 percent of the world's supertalls wouldn't actually be supertalls at all. The Burj Khalifa would lose more than 700 feet. If an angry giant broke off the Burj's spire and planted it on the ground, it'd still be the 11th tallest building in Europe. The worst offender of all is the Burj Al Arab, of which 39 percent is vanity spire [13].

In Table 4, there are some examples of vanity height of tall buildings.

If the author adds the vanity height $(194 \mathrm{~m})$ of Burj Khalifa then author's 1000.8 meters tower would be $1194.8 \mathrm{~m}$.

\section{Author's 831 Meters High Tower by Applying Same Structural Arrangements (Comparison with the World's Existing Tallest Building)}

Author's $1 \mathrm{Km}$ tower has been reduced to $831.6 \mathrm{~m}$ tall (nearly same height of the World's existing Tallest Building). The $831.6 \mathrm{~m}$ tower height is achieved by removing $169.2 \mathrm{~m}$ from the top of the $1000.8 \mathrm{~m}$ tower.

Results of the analysis show that drift and acceleration at $831.6 \mathrm{~m}$ (top) are $1041 \mathrm{~mm}$ and 26.9 milli-g (acceptable) respectively. So the habitable/usable floor is at height $831.6 \mathrm{~m}$ (231 stories). Whereas the world tallest building (Burj Khalifa) will have a drift of $2000 \mathrm{~mm}$ [14] at top $(828 \mathrm{~m})$ and habitable floor at height $584.5 \mathrm{~m}$ (154 stories).

\section{Covered Vertical Area at Base and Structural Materials}

Area covered by shear walls at ground floor $=1440.24 \mathrm{~m}^{2}$ Area covered by columns at ground floor $=72 \mathrm{~m}^{2}$

Gross area at ground floor $=102 \mathrm{~m} \times 102 \mathrm{~m}=10,404 \mathrm{~m}^{2}$ Area covered by vertical elements (shear walls and columns) at ground floor in percentage

$$
[(1440.2+72) / 10,404] \times 100 \geq 14.53 \% \text {. }
$$

Note: Percentage of gross floor area with respect to vertical elements (shear walls and columns) is one of the main efficiencies of structural arrangements.

This one kilometer high tower requires Young's Modulus of 42,038 MPa and 
compressive strength of $80 \mathrm{MPa}$ for columns, shear walls and Young's Modulus of 29,725 MPa and compressive strength of $40 \mathrm{MPa}$ for beams and slabs.

\section{Impact on Sway for Different Tier Heights}

During the research work, the structure is analyzed in two different shapes (Type-1 \& Type-2). The total height, thickness \& sizes of the structural members are kept the same. Only the Tier heights have been changed.

a) Type-1 (Equal Tier height): This building consisted of five Tiers. Height of first 4 Tiers from bottom is $226.8 \mathrm{~m}$ each \& height of top Tier is $93.6 \mathrm{~m}$. The result of the analysis show that sway at top is $220.18 \mathrm{~mm}$.

b) Type-2 (Different Tier heights) There are 4 different Tier heights keeping the top Tier height same as Type-1. Tier-1 (280.8 m), Tier-2 (244.8 m), Tier-3 $(208.8 \mathrm{~m})$ \& Tier-4 $(172.8 \mathrm{~m})$. The result of the analysis shows that the sway at top is $1930 \mathrm{~mm}$. So it is observed that the height of Tiers greatly influence the drift (sway) of the structure.

\section{Three Different Models of Height 734.4 Meters Analyzed by Developing Author's Structural Concept}

A 734.4 meters high tower is modeled in three different shapes. Model-1 holds 3 Tiers with Aspect Ratio 7.2:1 (Figure 13), Model-2 holds three Tiers with Aspect Ratio 9.415:1 (Figure 14), \& Model-3 holds four Tiers with Aspect Ratio 9.415:1 (Figure 15). The shapes $\&$ analysis results of these models are shown in Table 5.

\section{Philosophy behind This One Kilometer Tower's Structural Arrangements}

Consider a beam cantilevered from the earth. When lateral forces are applied to the beam, the beam will bend. The maximum compression and tension stresses will be on the two opposite sides along the force direction. Tension and compression will decrease linearly towards middle \& will be zero at the mid. Now consider a mega tall building of height 1000.8 meters and base $102 \mathrm{~m} \times 102 \mathrm{~m}$ with the shear walls being placed perpendicular to the face of building (can be called "Shear Walls toward periphery") around the periphery and continuing towards center of the building for a certain distance (Figures 7-9) along the direction of force. Let the summation of moment of inertia be "Im" with respect to the line passing through the center \& the maximum stress will be at compression face say "el".

On the other hand if the same number of shear walls is placed around the center to make an inner core to resist the lateral force, the summation of moment of inertia will be less than "Im" \& the maximum stress at compression face will be greater than "el". As the deflection is inversely proportional to the inertia forces, the deflection will be more for inner core system.

So when the structure is becoming taller, it is wiser to consider the outer core arrangement concept (Shear walls toward periphery) for resisting lateral forces.

This concept with some additional structure arrangements is applied to the 


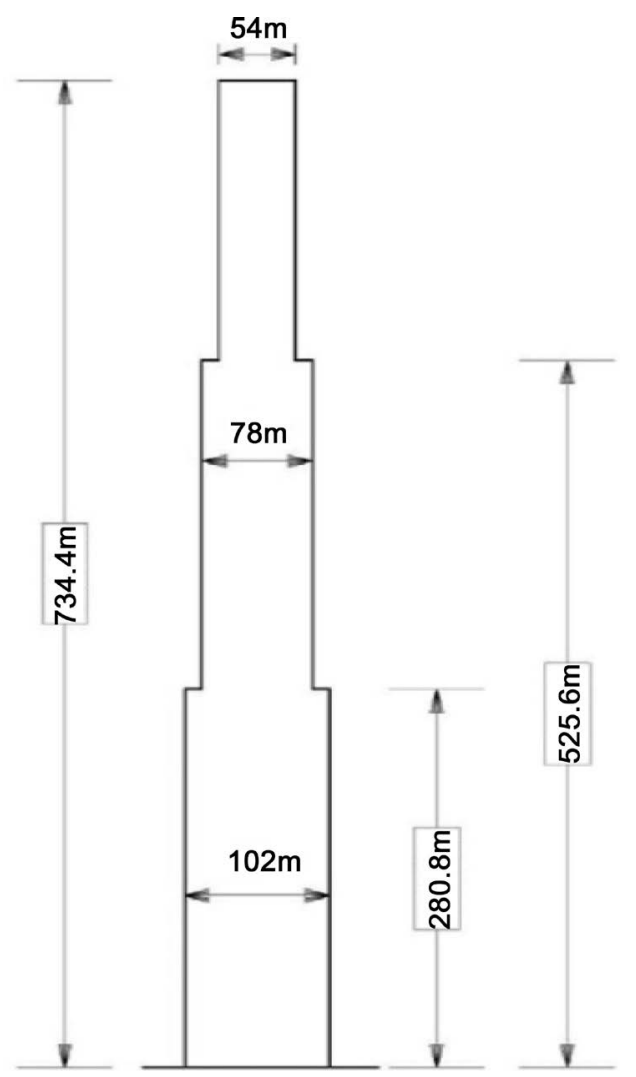

Figure 13. Model-1.

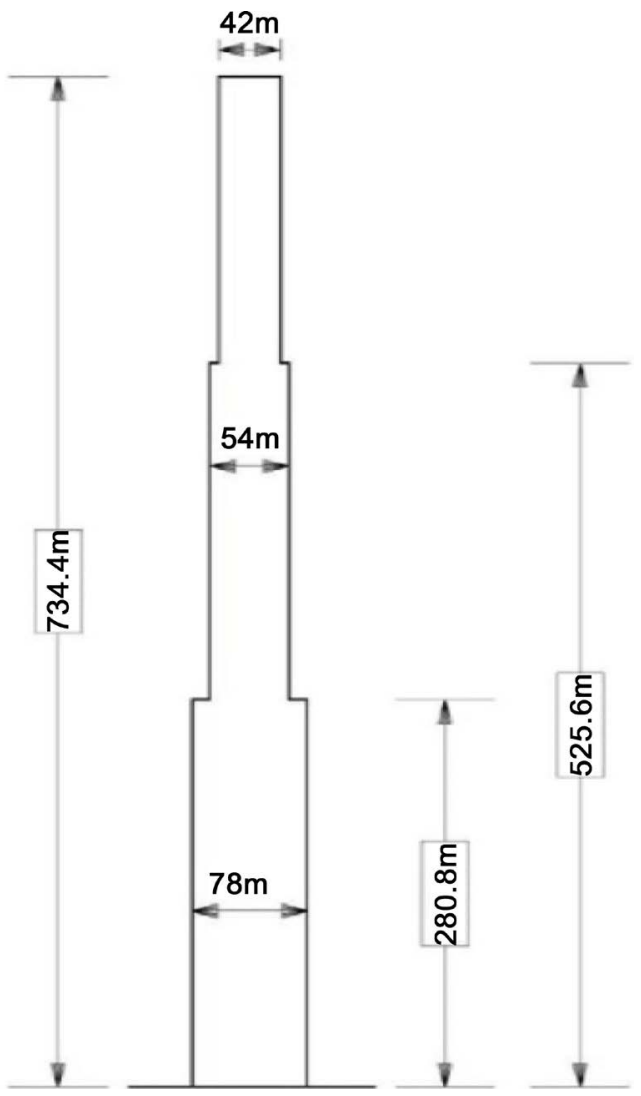

Figure 14. Model-2. 


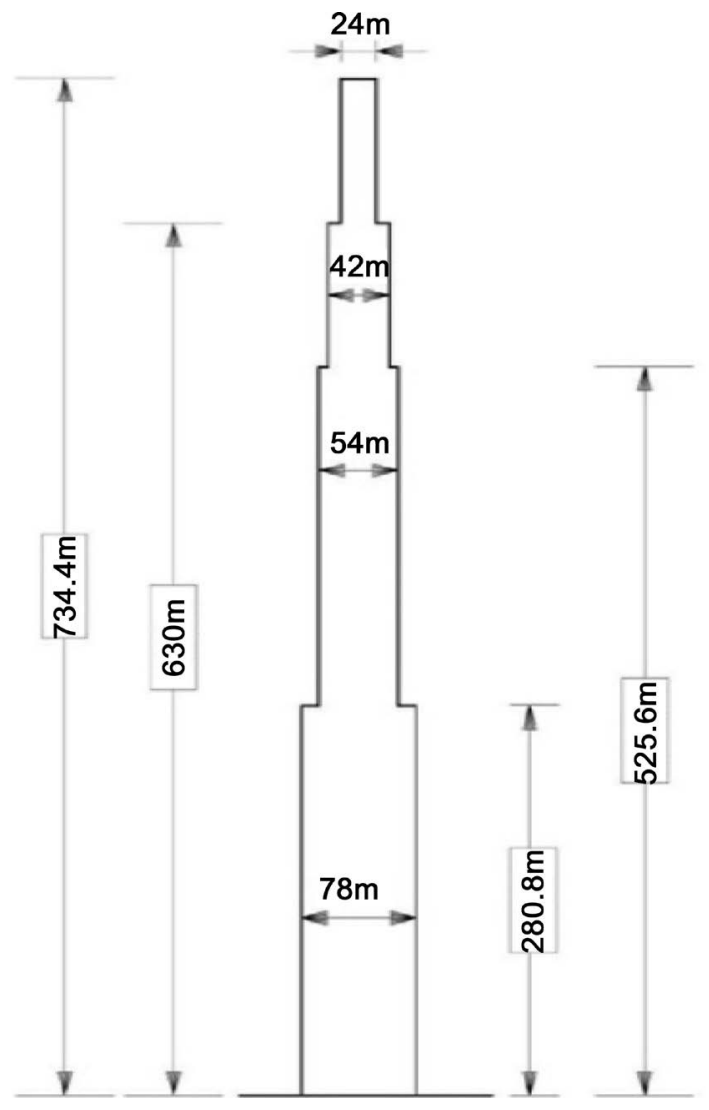

Figure 15. Model-3.

Table 5. Three different models.

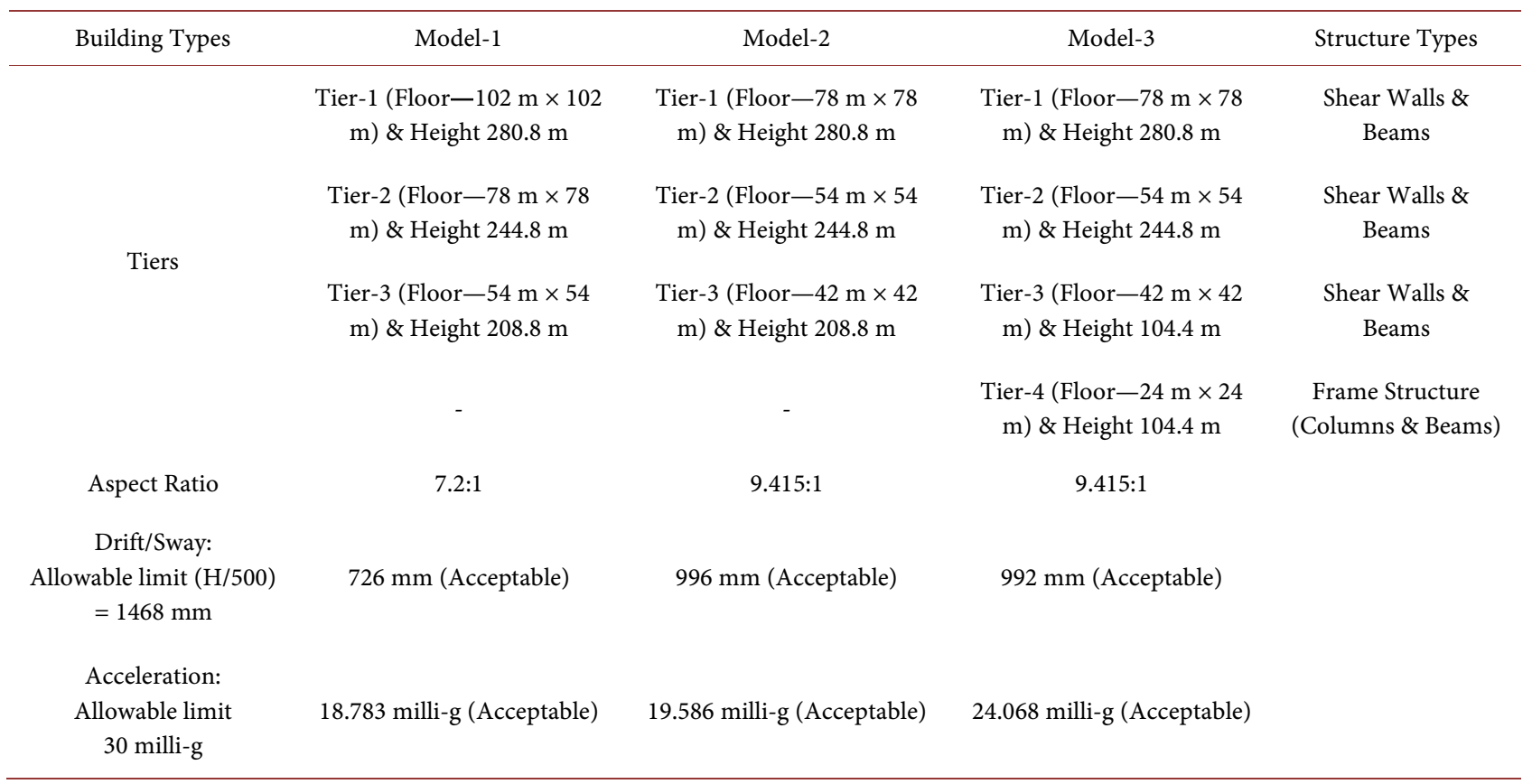

"One Kilometer Tower" research work. Figure 16 shows four different mode shapes due to wind forces.

To understand this phenomenon, consider the building as a cantilever beam. 

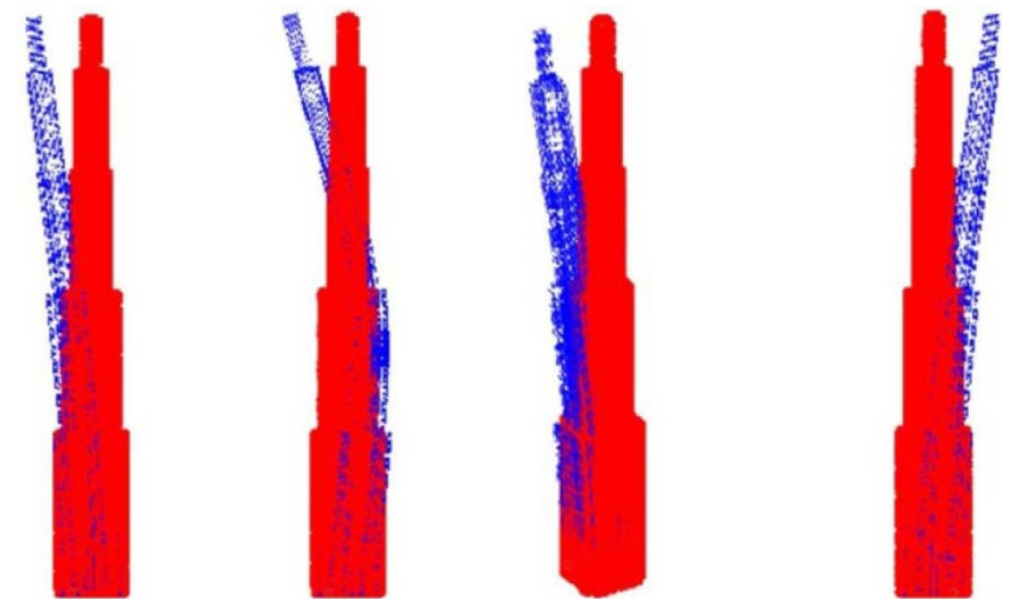

Figure 16. Four different mode shapes due to dynamic responses (Horizontal displacements are shown to large scale).

The horizontal cross sectional area at any height of the shear walls are considered the beam's sectional area which absorbs the bending and axial stresses and at the same time resists the deflection of the structure.

Figure 12 shows that when wind hits the structure at any face, the shear walls (Maroon color) which are parallel to the wind direction, connected by moment resisting members (beams), will mostly resist the lateral load by the composite action of the individual wall piers and the frame action resulting from the moment connection between them. Also the frame action between shear walls (perpendicular to wind direction) and the connecting beams will also resist part of the lateral loads (Figure 12).

\section{Basic Concept for Tower of Different Heights}

The proper arrangement of the shear walls is the main task of this concept. The shear walls arrangement as shown in the figures is sufficient to withstand One Kilometer High Tower with aspect ratio around 9.8:1. For the tower of lower heights, the structural engineer can minimizes length \& thickness of the shear walls in every grid, and can maximizes the spacing of the shear walls in a grid as well as the grid spacing (Figures 7-10). But the shear walls in a grid should be connected with the beams to get composite action of the shear walls. The grids and the shear walls in a grid can be moved, if required for the architectural issue. But it should be kept in mind that the centroid of all the shear wall's cross sections should be as near as possible to the mid of building's face to minimize the twisting effects of the building due to lateral loads.

\section{Advantages of This New Structural Concept}

1) The main concept of this system is to place the shear walls parallel to each other. When wind force is applied to the structure, each grid (consisting of several shear walls) will function individually to resist the wind force of their average span length (Figure 6 \& Figure 17). Due to this phenomenon, when this structural system is subjected to lateral loads such as wind load, the axial 


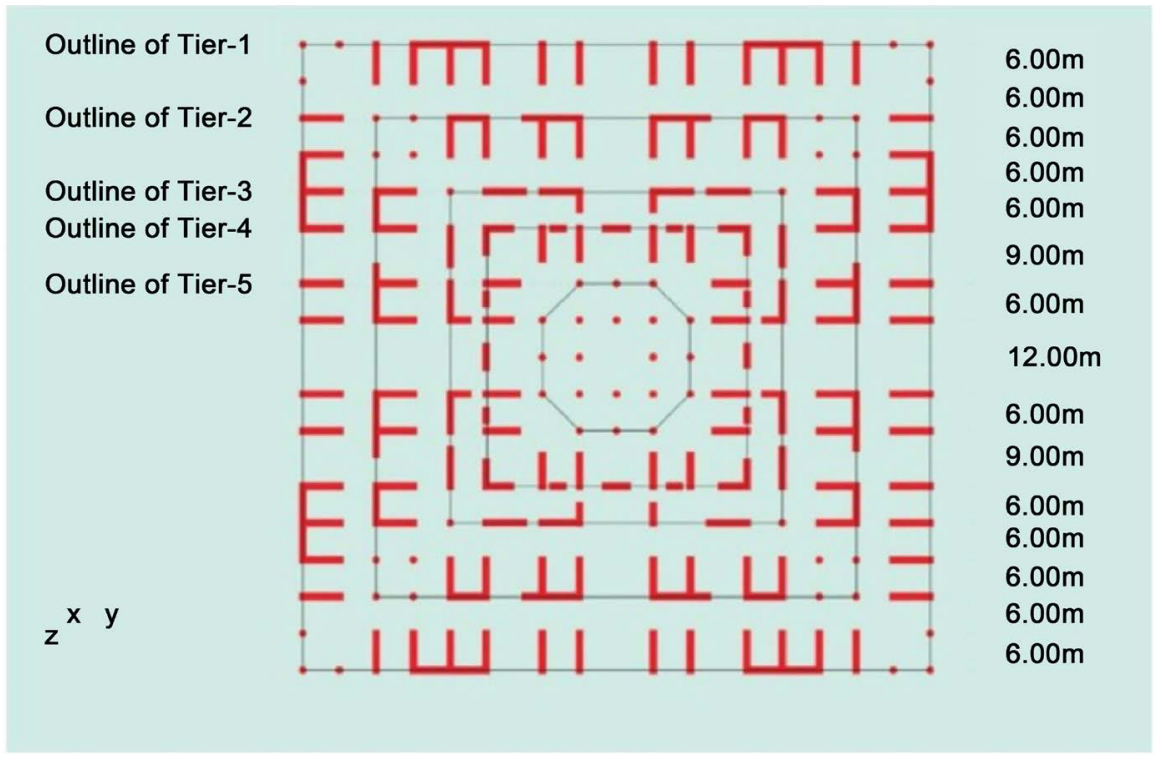

Figure 17. Typical shear walls spacing (Red lines \& circles indicate shear walls \& columns respectively).

stresses in the shear walls is nearly linear. Therefore Shear Lag effect is minimized.

2) Shear walls can be moved on both sides from mid (if required for architectural demands) by keeping the area of centroid of the vertical sections at the same position. This will make negligible effect on sway.

3) The shear walls are placed almost uniformly over the base, so the gravity loads are distributed almost uniformly to all the vertical elements (shear walls). Therefore, reduce the differential settlement.

4) Plenty of natural sunlight will pass through the building perimeter due to parallel shear wall arrangements.

5) Simple structural system.

6) No additional lateral load resisting system is required, like outriggers, belts or cross bracings, except tuned mass dampers (TMD).

7) Parallel shear walls from both the direction forming a perpendicular arrangement. The effect of the perpendicular walls will be to stiffen the structure in torsion, to reduce the twist, and, in doing so, to influence the contributions to the parallel wall shear and moment that result from the structure's twisting [[5], p. 189].

\section{Conclusions}

Engineering field professionals are trying to build buildings taller than the existing tallest ones. Generally these high-rise buildings require additional lateral systems to control the drift. But the use of the "Parallel Shear Walls" concept in Skyscraper design is a relatively new idea which does not take any help of additional lateral systems except TMD (If the building's height is above 850 meters). This structural arrangement can be applied to any tall building of any height to get a perfect and optimized structure. 
The research work carried out on three models of heights 1000.8 meters, 830 meters \& 734 meters with this structural arrangement. It is observed that the structures of heights 830 meters \& 734 meters have less value for drift and acceleration than the allowable limits as per international codes/standards. No bracings, outriggers or damper is required for such mega tall structures. Only damping system is required for 1000.8 meter high structure. That is, this "Innovative Structural Arrangement" is a simple method to go for tall and mega tall structures.

The details and further analysis of the structural models are kept (ETABS \& STAAD/PRO softwares) for reference can be discussed as needed.

Note: A book is published on 2012-12-26 (ISBN-13: 978-3-639-66041-8, author: Feroz Alam) in details on this concept from "Scholars' Press" (Omni Publisher). The title of the book is "Innovative Concept on Structural Engineering of Mega Tall Buildings". Part-2 of this book describes the concept of concrete reduction (minimum 8\%) from shear walls without affecting the structural integrity of tall buildings. This concept is suitably applicable for the buildings above 30 stories. The book is available in Amazon.com, MoreBooks and many other European websites.

\section{Acknowledgements}

The research work would not have achieved without the support, advice and endless effort from my senior colleague Professor Mr. M Ali, Ph.D., S.E., Fellow ASCE, Fellow CTBUH, Professor Emeritus of Structure, Adjunct Professor, University of Illinois at Urbana-Champaign. I am immensely grateful for the invaluable guidance, support and encouragement from him. Over the years of my study, I have benefited greatly from his wisdom and experience. I sincerely appreciate all the help received from him during the research work. Comments by the reviewers significantly contributed to the quality of this paper. I appreciate to my family members, wife Sharmin Alam, son Faizan Tazwar Alam and my sister Khurshida Ahmed (Polly) for their encouragements on my research project. Finally I thank to Engr. Anwar Hossain Akon, Dr. Habibur Rahman (AuthorThe Emergence of Qatar) and my brother Dr. Parvez Alam-USA for providing encouragements, suggestions/comments on this research.

\section{References}

[1] Francis, D.K., Ching, B.S.O. and Zuberbuhler, D. (2014) Building Structures Illustrated-Patterns, System, and Design. 2nd Edition.

[2] Klemencic, R. (2014) Why Are Tall Buildings Often Considered Safer than LowRise Buildings During Earthquakes? CTBUH Journal, No. 3, 58.

[3] Ali, M.M. (2001) Art of Skyscraper-The Genius of Fazlur Khan.

[4] Sinn, R. (2012) Taller: How Future Skyscraper Will Beat the Burj Khalifa.

[5] Smith, B.S. and Coull, A. (1991) Tall Building Structures.

[6] ASCE 7-10, Commentary Appendix C, Sec: CC.1.2.

[7] Kareem, A., Kijewski, T. and Tamura, Y. (1999) Mitigation of Motion of Tall 
Buildings with Specific Examples of Recent Application. Techno-Press, 2.

[8] Taipei Mass Damper. Wikipedia, the Free Encyclopedia.

[9] Tuned Mass Damper. Wikipedia, the Free Encyclopedia.

[10] Rizk, A.S. (2010) Structural Design of Reinforced Concrete Tall Buildings, CTBUH Technical Paper, Published CTBUH Journal Issue 1.

[11] Jayachandran, P. (2009) Design of Tall Buildings-Preliminary Design and Optimization.

[12] Taylor-Foster, J. (2013) Tall Buildings in Numbers. Vanity Height: The Empty Space in Todays Tallest.

[13] Campbell-Dollaghan, K. (2013) Spire Shame: Why Today's Tallest Buildings Are Mostly Just Spire.

[14] Feblowitz, J.C. (2010) Confusing the Wind: The Burj Khalifa Mother Nature, and the Modern Skyscraper.

Submit or recommend next manuscript to OALib Journal and we will provide best service for you:

- Publication frequency: Monthly

- 9 subject areas of science, technology and medicine

- Fair and rigorous peer-review system

- Fast publication process

- Article promotion in various social networking sites (LinkedIn, Facebook, Twitter, etc.)

- Maximum dissemination of your research work

Submit Your Paper Online: Click Here to Submit

Or Contact service@oalib.com 